\title{
RECOVERY OF SOIL PHYSICAL PROPERTIES BY GREEN MANURE, LIMING, GYPSUM AND PASTURE AND SPONTANEOUS NATIVE SPECIES ${ }^{(1)}$
}

\author{
Carolina dos Santos Batista Bonini ${ }^{(2)} \&$ Marlene Cristina Alves ${ }^{(3)}$
}

\begin{abstract}
SUMMARY
Inadequate usage can degrade natural resources, particularly soils. More attention has been paid to practices aiming at the recovery of degraded soils in the last years, e.g, the use of organic fertilizers, liming and introduction of species adapted to adverse conditions. The purpose of this study was therefore to investigate the recovery of physical properties of a Red Latosol (Oxisol) degraded by the construction of a hydroelectric power station. In the study area, a soil layer about $8 \mathrm{~m}$ thick had been withdrawn by heavy machines leading not only to soil compaction, but resulting in high-degree degradation. The experiment was arranged in a completely randomized design with nine treatments and four replications. The treatments consisted of: 1- soil mobilization by tilling (to ensure the effect of mechanical mobilization in all treatments) without planting, but growth of spontaneous vegetation; 2- Black velvet bean (Stizolobium aterrimum Piper \& Tracy); 3- Pigeonpea (Cajanus cajan (L.) DC); 4- Liming + black velvet bean; 5Liming + pigeonpea until 1994, when replaced by jack bean (Canavalia ensiformis); 6- Liming + gypsum + black velvet bean; 7- Liming + gypsum + pigeonpea until 1994, when replaced by jack bean; and two controls as reference: 8 - Native Cerrado vegetation and 9- bare soil (no tilling and no planting), left under natural conditions and in this situation, without spontaneous vegetation. In treatments 1 through 7 , the soil was tilled. Treatments were installed in 1992 and left unmanaged for seven years, until brachiaria (Brachiaria decumbens) was planted in all plots in 1999. Seventeen years after implantation, the properties soil macroporosity, microporosity, total porosity, bulk density and aggregate stability were assessed in the previously described treatments in the soil layers $0.00-0.10 ; 0.10-0.20$ and 0.20-0.40 m, and soil Penetration Resistance and soil moisture in 0.00-0.15 and 0.15-0.30 m. The plants were evaluated for: brachiaria dry matter and spontaneous growth of native tree species in the plots as of 2006. Results were analyzed by
\end{abstract}

\footnotetext{
(1) Part of the Master's Dissertation of the first author. Received for publication in July 14, 2009 and approved in April 4, 2011.

${ }^{(2)}$ Student of Pos-Graduate, Agronomy, FE, UNESP. CEP 15385-000 Ilha Solteira (SP), Brazil. FAPESP Scholarship. E-mail: carolsbatistabonini@hotmail.com

(3) Titular Professor, Departament of Fitossanidade, Rural Engineering and Soil, FE, UNESP. CNPq Scholarship. E-mail: mcalves@agr.feis.unesp.br
} 
variance analysis and Tukey's test at $5 \%$ for mean comparison. In all treatments, except for the bare soil (no recovery measures), ongoing recovery of the degraded soil physical properties was observed. Macroporosity, soil bulk density and total porosity were good soil quality indicators. The occurrence of spontaneous native species indicated the soil recovery process. The best adapted species was Machaerium acutifolium Vogel, with the largest number of plants and most advanced development; the dry matter production of $B$. decumbens in recovering soil was similar to normal conditions, evidencing soil recovery.

Index terms: soil bulk density, total porosity, soil degradation, soil quality.

\title{
RESUMO: RECUPERAÇÃO DAS PROPRIEDADES FÍSICAS DO SOLO POR MEIO DE ADUBOS VERDES, CALAGEM, GESSO, PASTAGEME ESPÉCIES DE OCORRÊNCIA ESPONTÂNEA
}

\begin{abstract}
O uso inadequado pode degradar os recursos naturais, sobretudo o solo. Práticas visando à recuperação de solos degradados têm recebido mais atenção nos últimos anos, por meio do uso de adubos orgânicos, correção do solo e implantação de espécies adequadas às condições adversas. Nesse sentido, desenvolveu-se o presente trabalho com o objetivo de investigar a recuperação das propriedades físicas de um Latossolo Vermelho degradado devido à construção de usina hidrelétrica. Na área estudada, foi retirada uma camada de solo de aproximadamente $8 \mathrm{~m}$ de espessura, com o uso de máquinas pesadas, o que causou compactação do solo, caracterizando alto grau de degradação. O delineamento experimental utilizado foi inteiramente casualizado, com nove tratamentos e quatro repetições. Os tratamentos foram: 1-solo mobilizado pelo preparo (para se obter o efeito mecânico da mobilização em todos os tratamentos) e sem plantio, deixando a ocorrência de vegetação espontânea; 2-mucuna-preta (Stizolobium aterrimum Piper \& Tracy); 3-guandu (Cajanus cajan (L.) Millsp) até 1994, sendo depois substituído por feijão-de-porco (Canavalia ensiformis (L.) DC); 4calcário+mucuna-preta; 5-calcário+guandu até 1994, sendo depois substituído por feijão-deporco; 6-calcário+gesso+mucuna-preta; 7-calcário+gesso+guandu até 1994, sendo depois substituido por feijão-de-porco; e, para controle, duas testemunhas, sendo: 8-vegetação nativa de Cerrado e 9-solo exposto (sem mobilização pelo preparo e sem plantio), deixado nas condições naturais e, nessa situação, sem vegetação espontânea. Nos tratamentos 1 a 7 o solo foi mobilizado pelo preparo. Os tratamentos foram instalados em 1992 e permaneceram por sete anos, até que em 1999 implantou-se Brachiaria decumbens em todas as parcelas experimentais. Após 17 anos de implantados os tratamentos descritos, foram avaliadas as propriedades: macroporosidade, microporosidade, porosidade total, densidade do solo e estabilidade de agregados nas camadas de 0,00-0,10,0,10-0,20 e 0,20-0,40 m, resistência do solo à penetração e umidade do solo $(0,00-0,15$ e 0,15-0,30 m). Com relação às plantas, foram avaliados a massa seca da braquiária e o crescimento das espécies arbóreas nativas que surgiram espontaneamente nas parcelas experimentais, sendo notadas a partir de 2006 . Os resultados foram analisados efetuando-se a análise de variância e o teste de Tukey a $5 \%$ para comparação de médias. Todos os tratamentos adotados, com exceção do solo exposto (sem intervenção para a sua recuperação), estão recuperando as propriedades físicas do solo degradado. A macroporosidade, densidade do solo e porosidade total foram bons indicadores da qualidade do solo. A ocorrência de espécies nativas espontâneas foi um indicativo do processo de recuperação do solo, e a espécie Machaerium acutifolium Vogel foi a mais adaptada, pelo maior número de plantas e maior desenvolvimento; a produção de massa seca de Brachiaria decumbens no solo em recuperação foi semelhante à do solo sob condição natural, atestando a sua recuperação.
\end{abstract}

Termos de indexação: densidade do solo, porosidade do solo, degradação do solo, qualidade do solo.

\section{INTRODUCTION}

Due to population growth and, consequently, economical development, environmental resources have been widely affected in the last decades.
Currently, of the natural resources degraded by anthropic actions, the natural characteristics of soil have been the most affected, mainly by inadequate exploration. The history of soil use shows that these alterations are not always followed by a new 
sustainable ecological system and that soils under intensive and improper use will be degraded (Alves \& Souza, 2008).

For the maintenance and improvement of the soil physical conditions, the addition and positive balance of organic matter is fundamental, based on the supply of organic matter, root action, macro- and microbiological activities and decomposition of organic matter (Alves, 1992).

In the recovery of a degraded soil the great challenge is the formation of a new horizon A, underlying the reestablishment of the surface layer and of other horizons (Noffs, 2000).

Vezzani \& Mielniczuk (2009) report that Brazilian researchers are seeking for more adequate soil quality indicators, proposing indicators related to physical (Alves et al., 2007), chemical (Ribeiro et al., 2007), and biological (Vargas \& Scholles, 2000) properties or a range of intergrated indicators (Araújo et al., 2007). These indicators are chosen according to the ease of use, and infrastructure and economic conditions. It is important to remember that a set of indicators is the most adequate option for a safe diagnosis.

The biological diversity and the intensity and duration of disturbances determine the resilience of ecosystems. Ecosystem restoration is the term attributed to the challenge to, by means of planned actions, recover soil structure - one of the fundamental conditions for restoration success - and consequently, improve aeration, mass/volume ratio, and soil water retention. This will create, the physical conditions for the re-establishment, also, of natural ecological processes, i.e., seed germination, seedling emergence and development, and return of vegetable residues to the soil, an energy source for soil organisms (Alves et al., 2007). In this context, Reis \& Kageyama (2003) add that crop succession is a complex and concomitant process, which improves soil conditions, the microclimate, as well as the diversity of flora, fauna and also decomposers.

Resilience represents the capacity of an ecosystem for regeneration after some natural or anthropogenic degradation (Aronson et al., 1994). The resilience of degraded areas is very low or nearly inexistent, due to the elimination of the means of natural regeneration, i.e., the soil seed bank and surface layer (Kageyama et al., 1992). In this case, restoration is a slow and difficult process, requiring a careful choice of plants with high growth capacity and good development in these degraded environments, as well as the use of soil management practices which support their recovery (Alves et al., 2007).

A number of techniques are used for restoration of degraded soils; most of them combine mechanical practices, to break up compact layers, with the input of organic matter. Alves et al. (2007); Kitamura et al. (2008) and Campos \& Alves (2008) reported improved soil quality by means of addition of organic matter (using green manure, sewage sludge) and confirmed the beneficial effects on the soil physical proprieties (bulk density, total porosity and macroporosity), in other words, a decrease in soil bulk density and increase in total porosity and macroporosity, as well as a better development of plants.

The problem of degradation in the study area was a consequence of the construction of the Hydroelectric Power Station Ilha Solteira, in São Paulo. Although power generation by water is considered one of the least harmful solutions, the dam constructions tend to cause strong degradation in many surrounding areas evidenced by, e.g., the withdrawal of vegetation and soil layers, as well as flooding. Therefore, among the areas affected by the dam constructions, there are "loan areas" (from which soil is removed for the foundations of the dam wall), as well as unstable slopes and wetlands, flooded areas, etc. (Alves \& Souza, 2008).

Due to the impact generated by the large civil constructions, it is necessary to develop techniques and alternatives for the recovery of these environments, where soil layers and the natural seed bank had been removed. Alves et al. (2007) studied the soil recovery of an area degraded by a civil construction, (hydroelectric plant), and concluded that soil quality improvement is possible by tilling, application of sewage sludge and green manuring, as indicated by the increased porosity, lower bulk density, improved water infiltration. Kitamura et al. (2008) reported the recovery of soil physical properties (bulk density, macroporosity, total porosity, aggregate stability) in another loan area degraded by soil removal for dam construction and that soil bulk density was the best physical indicator of the soil alterations.

In the search for solutions to the problems involving soil restoration, efforts are being made to identify the most adaptable species to the adverse conditions, as well as their positive effects on the soil proprieties, the recovery speed, and also to understand the factors associated to the resilience of the area under study, such as climate, water storage in the soil, and the capability of development of planted or spontaneous species. In this sense, some physical properties of a Red Latosol, under restoration for 17 years using green manure, liming, gypsum and pasture were evaluated, together with Brachiaria decumbens dry matter and spontaneous occurrence of native tree species.

\section{MATERIAL AND METHODS}

The study was conducted in a degraded area in Selvíria, State of Mato Grosso do Sul, (latitude $20^{\circ} 22^{\text {' }}$ South, longitude $51^{\circ} 22^{\prime}$ West, altitude $327 \mathrm{~m}$ asl). The mean annual rainfall in the region is $1,370 \mathrm{~mm}$, temperature $23.5^{\circ} \mathrm{C}$ and relative humidity between 70 and $80 \%$. The soil in the study area, by the Brazilian Soil Classification System is a dystrophic Red Latosol 
(Demattê, 1980; Embrapa, 2006), corresponding to an Oxisol by the US Soil Taxonomy.

From the area under study, a layer of $8.6 \mathrm{~m}$ had been withdrawn from the original soil surface for the construction of Hydroelectric Power Station Ilha Solteira, leaving the bare subsoil of the area exposed as of 1969 (Alves \& Souza, 2008). In 1992, the subsoil was surface-compacted and a little spontaneous vegetation had grown. In that year, restoration work was initiated. First, tilling was performed by subsoiling to an average depth of $0.41 \mathrm{~m}$. The soil was also plowed and harrowed with leveling disks and the soil analyzed physically and chemically: soil bulk density $=1.76 \mathrm{~kg} \mathrm{dm}^{-3} ; \mathrm{P}=0.5 \mathrm{mg} \mathrm{dm}^{-3} ; \mathrm{MO}=$ $5.5 \mathrm{~g} \mathrm{dm}^{-3} ; \mathrm{pH}\left(\mathrm{CaCl}_{2}\right)=4.1 ; \mathrm{K}=0.2 \mathrm{mmol}_{\mathrm{c}} \mathrm{dm}^{-3} ; \mathrm{Ca}^{2+}$ $=0.2 \mathrm{mmol}_{\mathrm{c}} \mathrm{dm}^{-3} ; \mathrm{Mg}^{2+}=1.0 \mathrm{mmol}_{\mathrm{c}} \mathrm{dm}^{-3} ;$ sum of bases $=3.2 \mathrm{mmol}_{\mathrm{c}} \mathrm{dm}^{-3} ; \mathrm{H}+\mathrm{Al}=20.0 \mathrm{mmol}_{\mathrm{c}} \mathrm{dm}^{-3}$; $\mathrm{CEC}=23.2 \mathrm{mmol}_{\mathrm{c}} \mathrm{dm}^{-3}$ and $\mathrm{V}=14 \%$.

Soil particle-size analysis determined $235 \mathrm{~g} \mathrm{~kg}^{-1}$ clay, $30 \mathrm{~g} \mathrm{~kg}^{-1}$ silt and $750 \mathrm{~g} \mathrm{~kg}^{-1}$ sand, in the soil under natural vegetation. In the loan area, after withdrawal of a $8.6 \mathrm{~m}$ thick surface layer, $261 \mathrm{~g} \mathrm{~kg}^{-1}$ clay, $152 \mathrm{~g} \mathrm{~kg}^{-1}$ silt and $662 \mathrm{~g} \mathrm{~kg}^{-1}$ sand was found. Under both conditions, the textural soil class is sandy clay loam.

Liming was based on the chemical characterization of the experimental area. Lime was applied to raise base saturation to $70 \%$, and in the treatments which included lime and gypsum, $25 \%$ of lime $\mathrm{CaO}$ weas replaced by $25 \%$ of gypsum $\mathrm{CaO}$, which were both incorporated into the soil.

The green manure species (Stizolobium aterrimum, Cajanus cajan and Canavalia ensiformis) were sown by hand in December and January, from 1992 to 1996 , at a density of 10 seeds $\mathrm{m}^{-2}$ and row spacing of $0.50 \mathrm{~m}$. The green manure management consisted of mowing the plants and leaving them on the surface.

In 1996, four years after treatment installation, the soil was limed again, based on chemical analysis, only in the treatments with lime and lime + gypsum.
The substitution of lime by gypsum followed the same procedure as described above. Liming was applied to raise base saturation to $70 \%$ in the cases where it was $<60 \%$.

In January 1997, corn (Zea mays L.), an AG 405 hybrid, was sown in all experimental plots. Fertilization consisted of $250 \mathrm{~kg} \mathrm{ha}^{-1} 4-30-10$ NPK plus $0.3 \% \mathrm{Zn}$, without liming. In June 1998, black oat (Avena strigosa Schieb) was also sown in all experimental plots. In February 1999, the forage grass (Brachiaria decumbens Stapf.) was sown as soil protection and to provide organic matter. In 2006, the presence of native Cerrado tree species was assessed.

The experiment had a completely randomized design, consisting of nine treatments and four replications. A border of $2 \mathrm{~m}$ on all sides of each $10 \times 10 \mathrm{~m}$ plot was disregarded (assessed area $64 \mathrm{~m}^{2}$ ) and replications were $2 \mathrm{~m}$ apart from each other.

The treatments consisted of: (1) OT/B: soil tilling without planting, allowing growth of spontaneous vegetation, until 1999, followed by planting of brachiaria (Brachiaria decumbens); (2) SA/B: black velvet bean (Stizolobium aterrimum Piper \& Tracy) until 1999 and then replacement with brachiaria; (3) CC/CE/B: Pigeonpea (Cajanus cajan (L.) DC) until 1994, then replacement with jack bean (Canavalia ensiformis), and as of 1999, replacement with brachiaria; (4) L+SA/B: Liming + black velvet bean until 1999, when replaced with brachiaria; (5) L+CC/ CE/B: Liming plus pigeonpea until 1994, when replaced with jack bean, and as of 1999 , replaced by brachiaria; (6) L+GY+SA/B: Liming + gypsum + black velvet bean until 1999, then replaced by brachiaria; (7) $\mathrm{L}+\mathrm{GY}+\mathrm{CC} / \mathrm{CE} / \mathrm{B}$ : Liming +gypsum+pigeonpea until 1994, when replaced by jack bean, and as of 1999, replaced by brachiaria, and two controls as reference; (8) NV: Native Cerrado vegetation and (9) BS: Bare soil (no tilling and no planting) (Table 1).

The controls bare soil and native Cerrado were included for comparison among treatments, so as to monitor the recovery of the studied physical

Table 1. Treatments used in the experimental area (1992-2008)

\begin{tabular}{|c|c|c|c|c|c|}
\hline \multirow{2}{*}{ Treatment } & \multicolumn{2}{|c|}{ Treatment } & \multicolumn{3}{|c|}{ Culture } \\
\hline & $(1992-1994)$ & (1994-1997) & 1997 & 1998 & (1999-2008) \\
\hline $\mathrm{OT} / \mathrm{B}$ & Tilling only, spontaneous vegetation & Tilling only, spontaneous vegetation & Zea mays & Avena atrigosa & B. decumbens \\
\hline $\mathrm{SA} / \mathrm{B}$ & Stizolobium aterrimum & Stizolobium aterrimum & Zea mays & Avena atrigosa & B. decumbens \\
\hline $\mathrm{CC} / \mathrm{CE} / \mathrm{B}$ & Cajanus cajan & Canavalia ensiformis & Zea mays & Avena atrigosa & B. decumbens \\
\hline $\mathrm{L}+\mathrm{SA} / \mathrm{B}$ & Lime + Stizolobium aterrimum & Lime + Stizolobium aterrimum & Zea mays & Avena atrigosa & B. decumbens \\
\hline $\mathrm{L}+\mathrm{CC} / \mathrm{CE} / \mathrm{B}$ & Lime+Cajanus cajan & Canavalia ensiformis & Zea mays & Avena atrigosa & B. decumbens \\
\hline $\mathrm{L}+\mathrm{GY}+\mathrm{SA} / \mathrm{B}$ & Lime+Gypsum+ Stizolobium aterrimum & Lime+Gypsum+ Stizolobium aterrimum & Zea mays & Avena atrigosa & B. decumbens \\
\hline $\mathrm{L}+\mathrm{GY}+\mathrm{AS} / \mathrm{CE} / \mathrm{B}$ & Lime+Gypsum+Stizolobium aterrimum & Canavalia ensiformis & Zea mays & Avena atrigosa & B. decumbens \\
\hline NV & Savannah native vegetation & & & & \\
\hline BS & Exposed soil (no treatment) & & & & \\
\hline
\end{tabular}

SA: Stizolobium aterrimum (Piper \& Tracy); CC: Cajanus cajan (L. Millsp); CE: Canavalia ensiformis (L.DC); Zea mays (L.); Avena strigosa (Schieb) and B: Brachiaria decumbens (Stapf.). 
characteristics as well as the evolution of the surface horizon. An approach of the physical properties of the exposed soil to those of soil under natural vegetation would mean the restoration of the degraded soil (anthropogenic intervention would be accelerating the recovery process). Differences observed in the recovery treatments compared to the control bare soil would indicate beneficial changes in the soil properties. These changes would be interpreted in comparison with the soil conditions under natural vegetation.

In January 2008, the following soil physical properties were assessed: soil bulk density, by the volumetric ring method; total porosity, by measuring soil saturation (total volume of water-filled soil pores); microporosity was assessed using the tension table and a water column of $6 \mathrm{kPa}$; and macroporosity was calculated from the difference between total porosity and microporosity. All evaluations were performed according to methodologies described by Embrapa (1997). The distribution and aggregate stability in water in this study is represented by the mean weighted diameter (MWD), according to Angers \& Mehuys methodology (2000). Soil Penetration Resistance was determined by a Penetrographer PAT SC-60 and soil moisture on a mass basis (Embrapa, 1997).

For the analysis, according to their specific characteristics, disturbed and non-disturbed soil samples were collected from three layers: $0.00-0.10$; $0.10-0.20$, and $0.20-0.40 \mathrm{~m}$. Soil Penetration Resistance as well as soil gravimetric moisture were assessed in the layers $0.00-0.15$ and $0.15-0.30$.
Dry matter mass was evaluated every three months. Plants from two points (contained in $1 \mathrm{~m}^{2}$ ) per plot were collected and weighed (drying at 60$70{ }^{\circ} \mathrm{C}$ to constant weight) and expressed in $\mathrm{kg} \mathrm{ha}^{-1}$. The stem diameter and height of tree species of spontaneous occurrence in the experimental area were assessed.

Results of soil physical evaluations were analyzed by variance analysis and Tukey test at $5 \%$ for mean comparison. Sisvar software (Ferreira, 2003) was used for the statistical analysis. It is emphasized that, for stem diameter and height of the spontaneous tree species, no statistical analysis was performed due to the variations in numbers of plants per plot (statistically not controlled because occurrence was spontaneous). Therefore, the plants were only characterized.

\section{RESULTS AND DISCUSSION}

Table 2 shows the significant difference among treatments in soil macroporosity, microporosity and bulk density as well as the MWD in all layers. For total porosity, significant differences were observed in all layers but $0.10-0.20$.

For macroporosity in the bare soil (degraded, no recovery measures) values were observed below the limit considered critical for a good development of the plant root system, i.e., $0.10 \mathrm{~m}^{3} \mathrm{~m}^{-3}$ (Baver, 1949; Greenland, 1981; Gupta \& Allmaras, 1987), in the

Table 2. Average figures for macroposity, microporosity, total porosity, soil bulk density and mean weighted diameter $(\mathrm{mm})$ in the layers $0.00-0.10,0.10-0.20$ and $0.20-0.40 \mathrm{~m}$, in the treatments studied, in 2008

\begin{tabular}{|c|c|c|c|c|c|c|c|c|c|}
\hline Property & OT/B & SA/B & $\mathrm{CC} / \mathrm{CE} / \mathrm{B}$ & $\mathrm{L}+\mathrm{SA} / \mathrm{B}$ & $\mathrm{L}+\mathrm{CC} / \mathrm{CE} / \mathrm{B}$ & $\mathrm{L}+\mathrm{GY}+\mathrm{SA} / \mathrm{B}$ & $\mathrm{L}+\mathrm{GY}+\mathrm{CC} / \mathrm{CE} / \mathrm{B}$ & NV & BS \\
\hline \multicolumn{10}{|c|}{$0.00-0.10 \mathrm{~m}$} \\
\hline Macroporosity $\left(\mathrm{m}^{3} \mathrm{~m}^{-3}\right)$ & $0.114 \mathrm{~B}$ & $0.093 \mathrm{AB}$ & $0.096 \mathrm{AB}$ & $0.133 \mathrm{BC}$ & $0.126 \mathrm{~B}$ & $0.094 \mathrm{AB}$ & $0.122 \mathrm{~B}$ & $0.184 \mathrm{C}$ & $0.055 \mathrm{~A}$ \\
\hline Microporosity $\left(\mathrm{m}^{3} \mathrm{~m}^{-3}\right)$ & $0.324 \mathrm{~B}$ & $0.319 \mathrm{~B}$ & $0.321 \mathrm{~B}$ & $0.298 \mathrm{AB}$ & $0.292 \mathrm{AB}$ & $0.305 \mathrm{AB}$ & $0.312 \mathrm{AB}$ & $0.270 \mathrm{~A}$ & $0.307 \mathrm{AB}$ \\
\hline Total Porosity $\left(\mathrm{m}^{3} \mathrm{~m}^{-3}\right)$ & $0.438 \mathrm{BC}$ & $0.415 \mathrm{ABC}$ & $0.419 \mathrm{BC}$ & $0.434 \mathrm{BC}$ & $0.419 \mathrm{BC}$ & $0.400 \mathrm{AB}$ & $0.434 \mathrm{BC}$ & $0.454 \mathrm{C}$ & $0.365 \mathrm{~A}$ \\
\hline Soil Bulk Density $\left(\mathrm{kg} \mathrm{dm}^{-3}\right)$ & $1.450 \mathrm{~B}$ & $1.485 \mathrm{~B}$ & $1.476 \mathrm{~B}$ & $1.423 \mathrm{~B}$ & $1.460 \mathrm{~B}$ & $1.512 \mathrm{~B}$ & $1.446 \mathrm{~B}$ & $1.265 \mathrm{~A}$ & $1.717 \mathrm{C}$ \\
\hline MWD (mm) & $2.261 \mathrm{AB}$ & $3.278 \mathrm{~B}$ & $2.246 \mathrm{AB}$ & $2.616 \mathrm{AB}$ & $3.232 \mathrm{~B}$ & $3.231 \mathrm{~B}$ & $3.087 \mathrm{~B}$ & $4.505 \mathrm{C}$ & $1.610 \mathrm{~A}$ \\
\hline \multicolumn{10}{|c|}{$0.10-0.20 \mathrm{~m}$} \\
\hline Macroporosity $\left(\mathrm{m}^{3} \mathrm{~m}^{-3}\right)$ & $0.061 \mathrm{~A}$ & $0.058 \mathrm{~A}$ & $0.055 \mathrm{~A}$ & $0.079 \mathrm{~A}$ & $0.066 \mathrm{~A}$ & $0.059 \mathrm{~A}$ & $0.060 \mathrm{~A}$ & $0.130 \mathrm{~B}$ & $0.055 \mathrm{~A}$ \\
\hline Microporosity $\left(\mathrm{m}^{3} \mathrm{~m}^{-3}\right)$ & $0.308 \mathrm{~B}$ & $0.305 \mathrm{~B}$ & $0.310 \mathrm{~B}$ & $0.300 \mathrm{~B}$ & $0.297 \mathrm{~B}$ & $0.302 \mathrm{~B}$ & $0.302 \mathrm{~B}$ & $0.242 \mathrm{~A}$ & $0.295 \mathrm{~B}$ \\
\hline Total Porosity $\left(\mathrm{m}^{3} \mathrm{~m}^{-3}\right)$ & $0.368 \mathrm{~A}$ & $0.375 \mathrm{~A}$ & $0.367 \mathrm{~A}$ & $0.375 \mathrm{~A}$ & $0.364 \mathrm{~A}$ & $0.362 \mathrm{~A}$ & $0.363 \mathrm{~A}$ & $0.375 \mathrm{~A}$ & $0.347 \mathrm{~A}$ \\
\hline Soil Bulk Density $\left(\mathrm{kg} \mathrm{dm}^{-3}\right)$ & $1.665 \mathrm{AB}$ & $1.666 \mathrm{AB}$ & $1.660 \mathrm{AB}$ & $1.609 \mathrm{AB}$ & $1.696 \mathrm{~B}$ & $1.633 \mathrm{AB}$ & $1.637 \mathrm{AB}$ & $1.527 \mathrm{~A}$ & $1.725 \mathrm{~B}$ \\
\hline $\operatorname{MWD}(\mathrm{mm})$ & $1.286 \mathrm{~A}$ & $2.053 \mathrm{~A}$ & $1.336 \mathrm{~A}$ & $1.736 \mathrm{~A}$ & $1.623 \mathrm{~A}$ & $1.678 \mathrm{~A}$ & $2.286 \mathrm{~A}$ & $3.902 \mathrm{~B}$ & $1.247 \mathrm{~A}$ \\
\hline \multicolumn{10}{|c|}{$0.20-0.40 \mathrm{~m}$} \\
\hline Macroporosity $\left(\mathrm{m}^{3} \mathrm{~m}^{-3}\right)$ & $0.066 \mathrm{~A}$ & $0.052 \mathrm{~A}$ & $0.045 \mathrm{~A}$ & $0.054 \mathrm{~A}$ & $0.061 \mathrm{~A}$ & $0.046 \mathrm{~A}$ & $0.057 \mathrm{~A}$ & $0.162 \mathrm{~B}$ & $0.032 \mathrm{~A}$ \\
\hline Microporosity $\left(\mathrm{m}^{3} \mathrm{~m}^{-3}\right)$ & $0.290 \mathrm{~B}$ & $0.305 \mathrm{~B}$ & $0.306 \mathrm{~B}$ & $0.293 B$ & $0.292 \mathrm{~B}$ & $0.300 \mathrm{~B}$ & $0.296 \mathrm{~B}$ & $0.237 \mathrm{~A}$ & $0.295 \mathrm{~B}$ \\
\hline Total Porosity $\left(\mathrm{m}^{3} \mathrm{~m}^{-3}\right)$ & $0.356 \mathrm{AB}$ & $0.359 \mathrm{AB}$ & $0.352 \mathrm{AB}$ & $0.348 \mathrm{~A}$ & $0.353 \mathrm{AB}$ & $0.347 \mathrm{~A}$ & $0.356 \mathrm{~A}$ & $0.400 \mathrm{~B}$ & $0.327 \mathrm{~A}$ \\
\hline Soil Bulk Density $\left(\mathrm{kg} \mathrm{dm}^{-3}\right)$ & $1.745 \mathrm{~B}$ & $1.730 \mathrm{~B}$ & $1.779 \mathrm{~B}$ & $1.766 \mathrm{~B}$ & $1.763 \mathrm{~B}$ & $1.799 B$ & $1.700 \mathrm{~B}$ & $1.397 \mathrm{~A}$ & $1.860 \mathrm{~B}$ \\
\hline MWD (mm) & $0.735 \mathrm{~A}$ & $1.300 \mathrm{~A}$ & $0.753 \mathrm{~A}$ & $1.343 \mathrm{~A}$ & $0.955 \mathrm{~A}$ & $0.781 \mathrm{~A}$ & $0.948 \mathrm{~A}$ & $2.760 \mathrm{~B}$ & $0.915 \mathrm{~A}$ \\
\hline
\end{tabular}

Averages followed by equal letters in rows did not differ from each other by Tukey test at $5 \%$. OT/B: soil tilled until 1999, followed by implantation of brachiaria; SA/B: Stizolobium aterrimum until 1999, and then brachiaria; CC/CE/B: Cajanus cajan until 1994, replaced then by Canavalia ensiformis, and as of 1999, replaced by brachiaria; L+SA/B: Liming + Stizolobium interrimum until 1999, replaced then by brachiaria; L+GY+SA/B: Liming + Gypsum + Stizolobium aterrimum until 1999, then replaced by brachiaria; L+GY+CC/CE/B: Liming + Gypsum + Cajanus cajan until 1994, then replaced by Canavalia ensiformis, and, as of 1999, replaced by brachiaria; NV: Native Cerrado vegetation; BS: bare soil. 
three soil layers studied. It is noteworthy that in layer $0.00-0.10 \mathrm{~m}$, three treatments approached the critical limit (SA/B; $\mathrm{CC} / \mathrm{CE} / \mathrm{B}$; L+GY/SA/B), while five exceeded it (OT/B; L+SA/B; L+GY/CE/B; NV), although there were no statistical differences among them. In terms of soil quality, this means that the physical conditions in treatments in which macroporosity exceeded the limit are better for a good development of the root system. Under natural Cerrado vegetation, macroporosity was higher in the three soil layers and statistically different from the other treatments.

The reduction in macroporosity in degraded soils results from increased compaction, as evidenced in the higher bulk density (Araújo et al., 2004; Camilotti et al., 2005). A similar behavior was observed by Campos \& Alves (2006) and Kitamura et al. (2008), in agreement with the observations in this study (Table 2).

In the layers $0.10-0.20$ and $0.20-0.40$, macroporosity was similar in the soils under treatment and the bare soil (degraded), indicating that the treatments had no effect below $0.10 \mathrm{~m}$. Effects in deeper layers take longer because the response to recovery of physical properties of Cerrado soils is slow (Alves \& Suzuki, 2004).

The physical properties of soils used as quality indicators show that the surface layer is being recovered (Table 2): macroporosity was higher and/or similar to the critical value; for soil with average texture, the values of bulk density were within the average bulk density range for this textural class $\left(1.40-1.50 \mathrm{~kg} \mathrm{dm}^{-3}\right)$. It is noted that the texture of the exposed soil (under study in this work) is sandyclay loam soil (258, 79 and $663 \mathrm{~g} \mathrm{~kg}^{-1}$ of clay, silt and sand, respectively) (Campos \& Alves, 2006; Kitamura et al., 2008).

A comparison of means of physical properties taken as indicators of soil quality among the recovery treatments (Table 2) showed a similar behavior in the studied soil layers. These findings corroborate results of Alves et al. (2007) in an area degraded by a power plant construction.

The data of total soil porosity and bulk density in the layer $0.00-0.10 \mathrm{~m}$ (Table 2) confirm the soil recovery in this layer. Total porosity was similar among the treatments used for soil restoration, but was greater than and statistically different from the bare soil (degraded). On the other hand, except for the treatment with $\mathrm{L}+\mathrm{GY}+\mathrm{SA} / \mathrm{B}$, results were similar in soil with natural Cerrado vegetation, indicating improvements in the soil structure. For soil bulk density, though, values were similar among the recovery treatments, lower than in the bare soil, and higher than under natural Cerrado vegetation.

In general there are similarities among the soil recovery treatments influencing the layer 0.00 $0.10 \mathrm{~m}$, corroborating results of Campos \& Alves (2006); Alves et al. (2007) and Kitamura et al. (2008).
It is worth highlighting the action of treatment lime+ black velvet bean/brachiaria, in $0.00-0.10 \mathrm{~m}$, with similar results to the soil under natural Cerrado vegetation. This means that the treatment is efficient in soil recovery, since the conditions are similar to those of a soil with natural vegetation. These results confirm findings of Alves (2001) and Alves et al. (2007).

In the surface layers $(0.10-0.20$ and $0.20-0.40 \mathrm{~m})$ data obtained in this study (Table 2) compared with data obtained in the same area by Andrade Júnior (2004) and Alves \& Souza (2008) show improvements in the soil physical quality, i.e, a restructuration of the soil occurred, reflected in the decrease of bulk density and increase of macroporosity and total porosity. Despite these improvements, it was noted that the physical properties were still degraded (smaller macroporosity, greater bulk density, less total porosity, compared to the critical limits and natural soil conditions). Reichert et al. (2003) stated that the evaluation of soil quality has both spatial and temporal dimensions. Intervals between measurements, to observe changes in the indicator assessed, depend on the period required for an action to produce quantifiable changes, and its frequency in space must take the spatial variations caused by the soil into account. Andrade Júnior (2004) mentions that, as time passes, brachiaria roots supply organic matter to the soil while the addition of organic matter by green manures and the brachiaria root system have a positive effect on the physical soil properties.

For soil penetration resistance in the layer 0.00 $0.10 \mathrm{~m}$, values were highest $(4.9 \mathrm{MPa})$ for the bare soil (Table 3). There was no difference between the soil with natural Cerrado vegetation and the recovery treatments, and values varied from 2.2 to 3.7 MPa. Many are the studies focused on the search for a critical value or a range of critical values of soil penetration resistance limiting plant growth, but uncertainties still remain about these limits, due to the diversity of behaviors of plants and soils (Reichert et al., 2007). It is known that the soil penetration resistance increases with soil degradation and compaction; limiting values to root growth vary from 1.5 to $3.0 \mathrm{MPa}$ (Grant \& Lanfond, 1993), from 2.0 to 4.0 MPa (Arshad et al., 1996), and in nop-tillage systems they reach 5.0 MPa (Ehlers et al., 1983). The recovery treatments show that the soil is being restored, since the soil penetration resistance showed that the soil was less compacted in the treatment areas than in the bare soil.

The determination of soil moisture at the moment of evaluation of soil penetration resistance is fundamental for a proper interpretation of the results. The moisture degree influences the evaluation by modifying cohesion among soil particles, which is greater in dry soils and decreases as the water content increases, causing particle detachment (Klein et al., 1998). Soil moisture was similar among treatments (Table 3). It is worth emphasizing the value of soil 
Table 3. Average values for soil penetration resistance and soil moisture, $F$ and variance coefficient, in the layers 0.00-0.15 and 0.15-0.30 m, in treatments studied, in 2008

\begin{tabular}{|c|c|c|c|c|c|c|c|c|c|}
\hline Property & OT/B & $\mathrm{SA} / \mathrm{B}$ & $\mathrm{CC} / \mathrm{CE} / \mathrm{B}$ & $\mathrm{L}+\mathrm{SA} / \mathrm{B}$ & $\mathrm{L}+\mathrm{CC} / \mathrm{CE} / \mathrm{B}$ & $\mathrm{L}+\mathrm{GY}+\mathrm{SA} / \mathrm{B}$ & $\mathrm{L}+\mathrm{GY}+\mathrm{CC} / \mathrm{CE} / \mathrm{B}$ & NV & BS \\
\hline & \multicolumn{9}{|c|}{$0.00-0.15 \mathrm{~m}$} \\
\hline Resistance to Penetration (MPa) & $3.2 \mathrm{ABC}$ & $2.4 \mathrm{AB}$ & $3.4 \mathrm{BC}$ & $3.7 \mathrm{C}$ & $3.1 \mathrm{ABC}$ & $3.0 \mathrm{ABC}$ & $2.2 \mathrm{~A}$ & $3.0 \mathrm{ABC}$ & $4.9 \mathrm{D}$ \\
\hline Soil Moisture $\left(\mathrm{kg} \mathrm{kg}^{-1}\right)$ & $0.10 \mathrm{~A}$ & $0.10 \mathrm{~A}$ & $0.10 \mathrm{~A}$ & $0.10 \mathrm{~A}$ & $0.10 \mathrm{~A}$ & $0.010 \mathrm{~A}$ & $0.15 \mathrm{~A}$ & $0.10 \mathrm{~A}$ & $0.09 \mathrm{~A}$ \\
\hline Value F - Resistance & $11.05^{*}$ & & CV-\% & 20.82 & & DMS-5\% & 1.074 & & \\
\hline \multirow[t]{2}{*}{ Value F - Unity } & $0.77^{\mathrm{ns}}$ & & CV- $\%$ & 38.70 & & DMS- $5 \%$ & 0.003 & & \\
\hline & \multicolumn{9}{|c|}{$0.15-0.30 \mathrm{~m}$} \\
\hline Resistance to Penetration (MPa) & $4.3 \mathrm{CD}$ & $3.2 \mathrm{ABC}$ & 3.8BCD & $4.2 \mathrm{CD}$ & 4.20 & $3.7 \mathrm{ABC}$ & $2.5 \mathrm{~A}$ & $3.0 \mathrm{AB}$ & $4.9 \mathrm{D}$ \\
\hline Soil Moisture $\left(\mathrm{kg} \mathrm{kg}^{-1}\right)$ & $0.12 \mathrm{ABC}$ & $0.13 \mathrm{BC}$ & $0.12 \mathrm{ABC}$ & $0.12 \mathrm{ABC}$ & $0.11 \mathrm{AB}$ & $0.12 \mathrm{ABC}$ & $0.12 \mathrm{ABC}$ & $0.13 \mathrm{~A}$ & $0.10 \mathrm{C}$ \\
\hline Value F - Resistance & $7.61_{*}^{*}$ & & CV-\% & 20.03 & & DMS- $5 \%$ & 1.207 & & \\
\hline Value F - Unity & $2.15^{*}$ & & CV-\% & 10.50 & & DMS-5\% & 0.029 & & \\
\hline
\end{tabular}

Averages followed by equal letters in rows did not differ from each other by Tukey's test at $5 \%$. OT: soil tilled until 1999, followed by implantation of brachiaria; SA/B: Stizolobium aterrimum until 1999, and then brachiaria; CC/CE/B: Cajanus cajan until 1994, replaced then by Canavalia ensiformis, and as of 1999, replaced by brachiaria; L+SA/B: Liming +Stizolobium interrimum until 1999, then replaced by brachiaria; L+GY+SA/B: Liming + Gypsum + Stizolobium aterrimum until 1999, then replaced by brachiaria; $\mathrm{L}+\mathrm{GY}+\mathrm{CC} / \mathrm{CE} / \mathrm{B}$ : Liming + Gypsum + Cajanus cajan until 1994, then replaced by Canavalia ensiformis, and, as of 1999, replaced by brachiaria; NV: Native Cerrado vegetation; BS: bare soil.

resistance under natural Cerrado vegetation (3.0 MPa), which was deemed high This was probably due to the low water content in the soil, since Campos (2006), for the soil in study (Red Latosol sandy-clay loam texture under natural Cerrado vegetation) observed that at this moisture level, the tension value in soil water was $200 \mathrm{kPa}$. Nevertheless, what is relevant is that the water content was similar among the treatments.

In the layer $0.15-0.30 \mathrm{~m}$ (Table 3 ), soil penetration resistance under Cerrado vegetation and in the recovery treatments with $\mathrm{SA} / \mathrm{B}, \mathrm{L}+\mathrm{GY}+\mathrm{SA} / \mathrm{B}$ and $\mathrm{L}+\mathrm{GY}+\mathrm{G} / \mathrm{CE} / \mathrm{B}$ was lower than in the bare (degraded) soil. But among the soil recovery treatments no difference was noted. This behavior is consistent with observations for soil porosity and bulk density, i..e, the treatments were more efficient in the soil surface layer.

For brachiaria dry matter production (Table 4), significance was noted for treatment and time, while the interaction of treatment $x$ time was not significant. When comparing all soil recovery treatments, the treatments $\mathrm{L}+\mathrm{GY}+\mathrm{CC} / \mathrm{CE} / \mathrm{B}$ and $\mathrm{L}+\mathrm{GY}+\mathrm{SA} / \mathrm{B}$ produced the most and the least amount of brachiaria dry matter, respectively. But among the other treatments there was no difference. It was expected that the treatment with lime and gypsum would be the most efficient in brachiaria dry matter production, which was not confirmed. Among the green manures, the performance of black velvet bean was better than of jack bean in terms of residual effects, reflected in the growth of brachiaria. In contrast, Andrade Júnior (2004), working in the same area, reported greater brachiaria dry matter production by the treatment $\mathrm{L}+\mathrm{GY}+\mathrm{CC} / \mathrm{CE}$, in disagreement with the results presented here. Brachiaria dry matter was equal to or higher than observed by Kawatoko (1999), who reported results between 1,818 to $2439 \mathrm{~kg} \mathrm{ha}^{-1}$ in Red
Latosol. This shows that this soil is in recovery process, since the values here found are equivalent to those in soil under natural conditions.

The occurrence of spontaneous tree species in the area was assessed in October 2007 and showed the presence of three species: Machaerium acutifolium Vogel, Solanum lycocarpum St. Hil and Mimosa lacticifera Rizini and Mattos Filho (Table 5). A total

Table 4. Average values of Brachiaria decumbens $\left(\mathrm{kg} \mathrm{ha}^{-1}\right)$ dry matter per treatments and cutting times

\begin{tabular}{|c|c|}
\hline Treatment & Dry mass production \\
\hline & $\mathrm{kg} \mathrm{ha}^{-1}$ \\
\hline OT/B & $2,505 \mathrm{AB}$ \\
\hline $\mathrm{SA} / \mathrm{B}$ & 3,077 \\
\hline $\mathrm{CC} / \mathrm{CE} / \mathrm{B}$ & $3,096 \mathrm{AB}$ \\
\hline $\mathrm{L}+\mathrm{SA} / \mathrm{B}$ & $3,148 \mathrm{AB}$ \\
\hline $\mathrm{L}+\mathrm{CC} / \mathrm{CE} / \mathrm{B}$ & $3,115 \mathrm{AB}$ \\
\hline $\mathrm{L}+\mathrm{GY}+\mathrm{SA} / \mathrm{B}$ & $3,522 \mathrm{~B}$ \\
\hline $\mathrm{L}+\mathrm{GY}+\mathrm{AS} / \mathrm{CE} / \mathrm{B}$ & $2,435 \mathrm{~A}$ \\
\hline DMS - $5 \%$ & 1,077 \\
\hline Time of cutting & Dry mass production $\left(\mathrm{kg} \mathrm{ha}^{-1}\right)$ \\
\hline $1^{\text {st }}$ cut - January & $2,917 \mathrm{~A}$ \\
\hline 2 st $\quad$ ut - April & $2,858 \mathrm{~A}$ \\
\hline 3 st cut - July & $3,712 \mathrm{~B}$ \\
\hline $4^{\text {st }}$ cut - October & $2,454 \mathrm{~A}$ \\
\hline $\mathrm{DMS}-5 \%$ & 707 \\
\hline \multicolumn{2}{|c|}{$\begin{array}{l}\text { OT: soil tilled until 1999, followed by implantation of brachiaria } \\
\text { SA/B: Stizolobium aterrimum until 1999, and then brachiaria } \\
\text { CC/CE/B: Cajanus cajan until 1994, replaced then by Canavalia } \\
\text { ensiformis, and as of } 1999 \text {, replaced by brachiaria; L+SA/B } \\
\text { Liming +Stizolobium interrimum until 1999, then replaced by } \\
\text { brachiaria; L+GY+SA/B: Liming + Gypsum + Stizolobium } \\
\text { aterrimum until 1999, then replaced by brachiaria; L+GY+CC } \\
\text { CE/B: Liming + Gypsum + Cajanus cajan until } 1994 \text {, then } \\
\text { replaced by Canavalia ensiformis, and, as of 1999, replaced by } \\
\text { brachiaria. }\end{array}$} \\
\hline
\end{tabular}


of 88 plants were identified of which 85 were $M$. acutifolium species, two $S$. lycocarpum, and one $M$. lacticifera. In 2009, the $S$. lycocarpum plants were no longer observed in the area, while three more $M$. acutifoliumt plants had grown, and one new plant of the species Curatella Americana L, of the family Dilleniaceae had appeared. The dynamics of the occurrence of these species in the study area was most likely related to their adaptation to the adverse soil conditions (degraded structure).

It can be noted that, of the three species which regrew naturally in the study area, one belonged to the family Fabaceae (M. lactifera). The Fabaceae are considered essential for the success of regeneration of a degraded area in view of their rusticity and high ability to provide the soil with organic matter (Costa, 2007).

When analyzing the development of the species Machaerium acutifolium Vogel, the species with the largest number, it was observed that this was the species with the greatest growth (height and diameter) in treatment $\mathrm{L}+\mathrm{GY}+\mathrm{CC} / \mathrm{CE} / \mathrm{B}$, followed by treatments $\mathrm{SA} / \mathrm{B}, \mathrm{CC} / \mathrm{CE} / \mathrm{B}$ and L+GY+SA/B (Table 5). Ferreira et al. (2007), when evaluating the development of tree species in an area degraded by the construction of a power plant, found that, of all species analyzed (Piptadenia gonoacantha, Inga affinis, Clitoria fairchildiana, Machaerium villosum, Anadenanthera colubrine, Acacia mangium, Cecropia pachystachya, Trema micrantha, Erythrina falcate and Acacia auriculiformis) the tallest species with the largest average diameters belonged to the family Fabaceae, reinforcing the thesis that the species of this family are fundamental for the recovery of degraded areas, because they grow fast in adverse environments. It is important to enhance their occurrence from the Amazon region across to São Paulo and Mato Grosso

Table 5. Growth of Machaerium acutiform Vogel plants from October 2007 to January 2009

\begin{tabular}{lccc}
\hline Treatment & Number of plants & Diameter & Height \\
\hline & & $\mathrm{cm}$ & $\mathrm{m}$ \\
OT/B & 21 & 0.41 & 0.67 \\
SA/B & 7 & 1.29 & 2.01 \\
CC/CE/B & 19 & 1.20 & 1.91 \\
L+SA/B & 13 & 0.11 & 0.42 \\
L+CC/CE/B & 9 & 0.76 & 1.83 \\
L+GY+SA/B & 10 & 1.04 & 1.18 \\
L+ GY+AS/CE/B & 5 & 1.87 & 2.96 \\
\hline
\end{tabular}

OT: soil tilled until 1999, followed by implantation of brachiaria; SA/B: Stizolobium aterrimum until 1999, and then brachiaria; CC/CE/B: Cajanus cajan until 1994, replaced then by Canavalia ensiformis, and as of 1999, replaced by brachiaria; L+SA/B: Liming + Stizolobium interrimum until 1999, then replaced by brachiaria; $\mathrm{L}+\mathrm{GY}+\mathrm{SA} / \mathrm{B}$ : Liming + Gypsum + Stizolobium aterrimum until 1999, then replaced by brachiaria; $\mathrm{L}+\mathrm{GY}+\mathrm{CC} /$ CE/B: Liming + Gypsum + Cajanus cajan until 1994, then replaced by Canavalia ensiformis, and, as of 1999, replaced by brachiaria. do Sul. The spontaneous incidence of this species in the recovering area, with the greatest number and development, show evidence of the efficiency of the treatments for soil recovery.

Some authors associate the competition of brachiaria with the development of other species. For Durigan et al. (1998), grasses (Poaceae) compete with the Cerrado species, slowing down, or even preventing the process of natural regeneration. Reis \& Kageyama (2003) however highlight that grasses in general produce substances capable of preventing the growth of other species by means of a process called antibiosis. On the other hand, this does not mean that they should be avoided in restoration processes in view of their capacity of colonization, of organic matter production and improvement in soil quality. Results of this study confirm information of Seitz (1994), who stated that anemochoric species tend to be the first to take root after total vegetation destruction.

As an anemochoric species, these plants may have been brought to the experimental area by wind dispersal of seeds from an adult plant. This is evidence of the importance of dispersal in the recovery processes of degraded areas. It can therefore be said that, for the species Machaerium acutifolium, the variable number of plants was influenced by the proximity of the matrix plant in relation to the experimental plots, once the highest number of plants of this species was found in the plots closest to the adult plant. Stem diameter and height of the plants were influenced by the treatments since the greatest average diameters were found in the plots treated with the combination of chemical fertilizers and green manure, particularly $\mathrm{L}+\mathrm{GY}+\mathrm{CC} / \mathrm{CE} / \mathrm{B}$. This reiterates the fact that the treatments are improving the characteristics of the recovering soil (Alves \& Souza, 2008), resulting in plant with better development in the fertilized plots.

It was observed that the species Machaerium acutifolium is not competitive since other plants were found around the matrix plant, and it can be stated that it provides conditions for the development of other species. No other plant of the same species was found near the matrix plant, making it evident that the experimental area (recovering environment) created beneficial conditions for the establishment of species, once the area under study had been recovering for 17 years, resulting in better conditions in relation to the ones found outside the experiment. In Table 5 the treatments with most plants can be observed, which means that the plots of those treatments were nearer the matrix plant. Spontaneous occurrence seemed to be more related to this proximity than to the treatments.

\section{CONCLUSIONS}

1. The soil physical proprieties are being recovered and soil macroporosity, total porosity and bulk density were good indicators of the soil quality. 
2. Spontaneous occurrence of native species, of which Machaerium acutifolium Vogel was the most adapted, were an index of the process of soil recovery.

3. Dry matter production of Brachiaria decumbens on recovering soil and on soil under natural conditions was similar.

4. The use of green manure associated to lime and gypsum for seven years, followed by Brachiaria decumbens for 10 years, plus the spontaneous occurrence of native species in action for three years were efficient to restore the soil in this study.

\section{ACKNOWLEDGEMENTS}

We thank FAPESP for the financial support granted.

\section{LITERATURE CITED}

ALVES, M.C. Recuperação do subsolo de um Latossolo Vermelho usado para terrapleno e fundação da usina hidrelétrica de Ilha Solteira - SP. Ilha Solteira, Universidade Estadual Paulista 2001. 83p. (Tese de Livre Docência)

ALVES, M.C. \& SUZUKI, L.E.A.S. Influência de diferentes sistemas de manejo do solo na recuperação de suas propriedades físicas. Acta, Sci., 26:27-34, 2004.

ALVES, M.C.; SUZUKI, L.G.A.S. \& SUZUKI, L.E.A.S. Densidade do solo e infiltração de água como indicadores da qualidade física de um Latossolo Vermelho distrófico em recuperação. R. Bras. Ci. Solo, 31:617-625, 2007.

ALVES, M.C. \& SOUZA, Z.M. Recuperação de área degradada por construção de hidroelétrica com adubação verde e corretivo. R. Bras. Ci. Solo, 32:2505-2516, 2008.

ALVES, M.C. Cultura do algodão, soja, milho e feijão em sucessão com quatro adubos verdes em dois sistemas de semeadura. Piracicaba, Escola Superior de Agricultura "Luiz de Queiroz", 1992. 173p. (Tese de Doutorado)

ALVES, M.C. \& SUZUKI, L.E. Influencia de diferentes sistemas de manejo do solo na recuperação de suas propriedades físicas. Acta Sci., 26:27-34, 2004.

ANDRADE JÚNIOR, R.T. Propriedades físico-químicas de um solo em Recuperação e adaptação da Brachiaria decumbens. Ilha Solteira, Universidade Estadual Paulista, 2004. $49 \mathrm{p}$

ANGERS, D.A. \& MEHUYS, G.R. Aggregate stability to water. In: CARTER, M.R. Soil sampling and methods of analysis. Canadian Soc. Soil Sci. Boca Raton, Lewis Publishers, 2000. p.529-539.

ARAÚJO, R.; GOEDERT, W.J. \& LACERDA, M.P.C. Qualidade de um solo sob diferentes usos e sob Cerrado nativo. R. Bras. Ci. Solo, 31:1099-1108, 2007.
ARAUJO, M.A.; TORMENA, C.A.; SILVA, A.P.A. \& MENDONÇA, E. Propriedades físicas de um Latossolo Vermelho distrófico cultivado e sob mata nativa. R. Bras. Ci. Solo, 28:337-345, 2004.

ARONSON, J.; FLORET, C.; FLOCH, E.; OVALLE, C. \& PONTANIER, R. Restoration and rehabilitation of degraded ecosystems in arid and semiarid lands. Rest. Ecol., 1:68-186, 1993.

ARSHAD, M.A.; LOWERY, B. \& GROSSMAN, B. Physical tests for monitoring soil quality. In: DORAN, J.W. \& JONES, A.J., eds. Methods for assessing soil quality. Madison, Soil Science Society of America, 1996. p.123141 (SSSA Special Publication, 49)

BAVER, L.D. Practical values from physical analyses of soils. Soil Sci., 68:1-13, 1949.

CAMILOTTI, F.; ANDRIOLI, I.; DIAS, F.L.F.; CASAGRANDE, A.A.; DA SILVA, A.R.; MUTTON, M.A. \& CENTURION, J.F. Efeito prolongado de sistemas de preparo do solo com e sem cultivo de soqueira de cana crua em algumas propriedades físicas do solo. Eng. Agric., 25:189-198, 2005.

CAMPOS, F.S. \& ALVES, M.C. Resistência à penetração de um solo em recuperação sob sistemas agrosilvopastoris, R. Bras. Eng. Agríc. Amb., 10:759-764, 2006.

CAMPOS, F.S. Uso de lodo de esgoto na reestruturação de Latossolo Vermelho degradado. Ilha Solteira, Universidade Estadual Paulista, 2006. 106p. (Tese de Mestrado)

CAMPOS, F.S. \& ALVES, M.C. Uso de lodo de esgoto na reestruturação de solo degradado. R. Bras. Ci. Solo, 32:1389-1397, 2008.

COSTA, C.D.O. Regeneração de espécies arbóreas em um subsolo degradado revegetado com Brachiaria decumbens Stapf. Aquidauana, Universidade Estadual de Mato Grosso do Sul, 2007. 42p. (Trabalho de Conclusão de Curso)

DEMATTÊ, J.L.I. Levantamento detalhado dos solos do Campus Experimental de Ilha Solteira (SP) Piracicaba, 1980. 131p. (Não Publicado)

DURIGAN, G.; CONTIÉRI, W.A.; FRANCO, G.A.D.C. \& GARRIDO, M.A.O. Indução do processo de regeneração da vegetação de Cerrado em área de pastagem, Assis, SP. Acta Bot. Bras., 3:421-429, 1998.

EHLERS, W.; KÖPKE, F.; HESSE, F. \& BÖHM, W. Penetration resistance and root growth of oats in tilled and untilled loess soil. Soil Tillage Res,, 3:261-275, 1983.

EMPRESA BRASILEIRA DE PESQUISA AGROPECUARIA EMBRAPA. Centro Nacional de Pesquisa do Solo. Manual de métodos de análise de solo. 2.ed. Rio de Janeiro, 1997. $212 \mathrm{p}$.

EMPRESA BRASILEIRA DE PESQUISA AGROPECUÁRIA EMBRAPA. Centro Nacional de Pesquisa de Solos. Sistema brasileiro de classificação de solos. Rio de Janeiro, 2006. 306p.

FERREIRA, D.F. Sisvar versão 4.2. Lavras, Universidade Federal de lavras, 2003. 
FERREIRA, W.C.; BOTELHO, S.A.; DAVIDE, A.C. \& FARIA, J.M.R. Avaliação do crescimento do estrato arbóreo de área degradada revegetada à margem do Rio Grande, na Usina Hidrelétrica de Camargos, MG. R. Árvore, 31:1-15, 2007.

GRANT, C.A. \& LANFOND, G.P. The effects of tillage systems and crop sequences on soil bulk density and penetration resistence on a clay soil in southern Saskatchewan. Canadian J. Soil Sci., 73:223-232, 1993.

GREENLAND, D.J. Soil Management and soil degradation. J. Soil Sci., 31:301-322, 1981.

GUPTA, S.C. \& ALLMARAS, R.R. Models to assess the susceptibility of soil to excessive compaction. Adv. Soil Sci., 6:65-100, 1987.

KAGEYAMA, P.Y.; REIS, A. \& CARPANEZZI, A.A. Potencialidades e restrições da regeneração artificial na recuperação de áreas degradadas. In: SIMPÓSIO NACIONAL DE RECUPERAÇÃO DE ÁREAS DEGRADADAS, Curitiba, 1992. Anais... Curitiba, 1992. p.1.

KAWATOKO, M. Produção e valor nutritivo de Brachiaria decumbens, Stapt em função da aplicação de calcário, nitrogênio e zinco em solo originalmente sob vegetação nativa de cerrado. Ilha Solteira, Universidade Estadual Paulista, 1999. 117p. (Tese de Mestrado)

KITAMURA, A.E.; ALVES, M.C.; SUZUKI, L.G.A.S. \& GONZALEZ, A.P. Recuperação de um solo degradado com a aplicação de adubos verdes e lodo de esgoto. R. Bras. Ci. Solo, 32:405-416, 2008.

KLEIN, V.A.; LIBARDI, P.L. \& SILVA, A.P. Resistência mecânica do solo à penetração sob diferentes condições de densidade e teor de água. Eng. Agric., 18:45-54, 1998.
NOFFS, P.S. Áreas degradadas, In: NOFFS, P.S.; GALLI, L, F. \& GONÇALVES, J.C. Recuperação de áreas degradadas da mata atlântica. 2.ed. São Paulo, Conselho Nacional da Reserva da Biosfera da Mata Atlântica, 2000. 48p.

RIBEIRO, K.A.; OLIVIERA, T.S.; MENDONÇA, E.S.; XAVIER, F.A.S.; MAIA, S.M.F. \& SOUSA, H.H.F. Qualidade do solo na cultura do cajueiro anão precoce cultivado sob diferentes sistemas de manejo. R. Bras. Ci. Solo, 3:341$351,2007$.

REICHERT, J.M.; REINERT, D.J. \& BRAIDA. J.A. Qualidade do solo e sustentabilidade de sistemas agrícolas. R. Ci. Amb., 27:29-48, 2003.

REICHERT, J.M.; SUZUKI, L.E.A.S. \& REINERT, D.J. Compactação do solo em sistemas agropecuários e florestais: Identificação, efeitos, limites críticos e mitigação. In: CERETTA, C.A.; SILVA, L.S. \& REICHERT, J.M. Tópicos em ciência do solo. Viçosa, MG, Sociedade Brasileira de Ciência do Solo, 2007. v.5. p.49-134.

REIS, A. \& KAGEYAMA, P.Y. Restauração de áreas degradadas utilizando interações interespecíficas. In: REIS, A. \& KAGEYAMA, P.Y. Restauração ecológica de ecossistemas naturais. Botucatu, FEPAF, 2003. p.93-108.

SEITZ, R.A.A. A regeneração natural na recuperação de áreas degradadas. In: SIMPÓSIO SUL AMERICANO, 1.; SIMPÓSIO NACIONAL, 2.; RECUPERAÇÃO DE ÁREAS DEGRADADAS, 1., Foz do Iguaçu, 1994. Anais... Curitiba, FUPEF, 1994. p.103-110.

VARGAS, L.K. \& SCHOLLES, D. Biomassa microbiana de produção de C-CO2 e $\mathrm{N}$ mineral de um Podzólico Vermelho-Escuro submetido a diferentes sistemas de manejo. R. Bras. Ci. Solo, 24:35-42, 2000.

VEZZANI, F.M. \& MIELNICZUK, J. Uma visão sobre qualidade do solo. R. Bras. Ci. Solo, 33:743-755, 2009. 